FILOZOFIA

Roč. 75,2020 , č. 1

DOI: https://doi.org/10.31577/filozofia.2020.75.1.4

\title{
NATIONAL CHARACTEROLOGY IN THE INTERWAR HUNGARIAN THOUGHT
}

GÁBOR KOVÁCS, Institute of Philosophy of the Research Centre for the Humanities, Budapest, Hungary

\author{
KOVÁCS, G.: National Characterology in the Interwar Hungarian Thought \\ FILOZOFIA, 75, 2020, No 1, pp. $40-50$
}

\begin{abstract}
The theory of Béla Hamvas on Hungarian national character is one of the less known aspects of his oeuvre concentrating upon the question of self-redemption with the help of ancient esoteric wisdom hidden in the holy books of different world religions. The paper puts the conception of Hamvas concerning national character into the interwar Hungarian and European context giving special emphasis to the German thought. The main hypothesis that national characterology was a reaction to the modernity-crisis of the interwar period that culminated in totalitarianism. Hamvas wasn't an exception to the rule in this respect: his national characterology had been intertwined with his cultural criticism: the core of his theory was the resacralization of soulless, profanized modernity. This is true for the theories of László Németh, János Kodolányi and Sándor Karácsony.
\end{abstract}

Keywords: National characterology - Modernity-crisis - Conservative revolution Cultural criticism - Alternative modernity - Re-enchantment of the modern world

International contexts: the emergence of national characterology in inter-war Europe and its causes

The 1920s were dominated by the spirit of self-sufficiency and self-containment in economic and intellectual sense as well. The modernity-crisis, whose first symptoms had been detected in the fin de siècle mood of late $19^{\text {th }}$ century now, after the cataclysm of the First World War, had reached its culminating point. Economic, social and mental structures inherited from the previous century were on the verge of collapse. The concrete forms of the crisis were different from country to country but there was a general matrix outlining behind them. The philosophy of progressivism, rooted in the optimism of Enlightenment had been discredited after the mechanized masskilling of the first total war of mankind; cyclical theories, à la the fashion of-Oswald Spengler and Arnold Toynbee, seemed to be correct and verifiable models of historic events. To conceptualize history as terrain of decay, as Verfallsgeschichte, seemed to 
be a plausible interpretation and enjoyed wide acceptance in the disillusioned afterwar atmosphere.

There is no better expression of this disillusionment than Walter Benjamin's fragment $n .9$ of historical philosophy in which he seemingly stays within the borders of the progressivist paradigm while, in the fact, he deconstructs the notion of progress inherited from the $18^{\text {th }}$ century which had conceptualized it as a linear, unstoppable melioration taking place in materialistic, spiritual and moral dimensions at the same time:

“A Klee painting named 'Angelus Novus' shows an angel looking as though he is about to move away from something he is fixedly contemplating. His eyes are staring, his mouth is open, his wings are spread. This is how one pictures the angel of history. His face is turned toward the past. Where we perceive a chain of events, he sees one single catastrophe which keeps piling wreckage upon wreckage and hurls it in front of his feet. The angel would like to stay, awaken the dead, and make whole what has been smashed. But a storm is blowing from paradise; it has got caught in his wings with such violence that the angel can no longer close them. This storm irresistibly propels him into the future to which his back is turned, while the pile of debris before him grows skyward. This storm is what we call progress" (Benjamin 1969, 257 - 258).

Tradition was a key notion to the contemporaries living among the debris of a fallen world. It appeared to be a magical tool which helps to reweave the torn thread of history. But it was not as simple as that. 'Which tradition?' - that was the Hamletian question at the time. Tradition inherited from the previous generations of the $19^{\text {th }}$ century, according to the public conviction of the 20 s, was not only unserviceable but explicitly harmful; it paved the way for later collapse during the war. The classical, value- conserving conservatism was an inadequate and outmoded political attitude in this new situation. The new conservatism broke with the idea of continuity and put the emphasis on discontinuity, the creation of an alternative tradition borrowed from the times preceding the era of unrestricted capitalism and liberal democracy of the $19^{\text {th }}$ century. This intellectual strategy resulted in the ambivalent and heterogeneous ideology of the conservative revolution in the after-war Weimarian Germany.

The contemporary national characterology, including the Hungarian and European scenes, had been rooted in the special interwar intellectual and political climate imbued with the ideas of conservative revolution. The label itself seems to be paradoxical: How can a conservative think a revolution to be a remedy for social and political troubles? Really, conservative revolution was a diffuse intellectual movement which, in Germany, had been canalised by journals and clubs but didn't take on solid institutional forms; it was not able to enter the political scene as a political party. At the same time, it remained a blurred but influential cultural-political option until the 
Nazi takeover inspiring very different thinkers from Oswald Spengler and Ernst Jünger to Carl Schmitt and Martin Heidegger (Mohler 1989, Woods 1996).

The cultural-political package of conservative revolution was extremely heterogeneous, burdened with ambivalences and inner contradictions therefore lent itself readily to different interpretations. The contents of this package were embarrassingly variegated: organic-cyclical philosophies of histories, morphological approach associated with Geistesgeschichte, vitalistic philosophy of Nietzsche, cultural criticism, ecological sensitivity. The most important, from the perspective of our subject, seems to be the yes and no given to the challenges of modernity at the same time. Conservative revolution was not an anti-modern movement in a fundamentalist way. Modernity had been refused by it in a special, selective manner: its intellectual, social, economic and political aspects, so rationalism, capitalism, modern class-society and political democracy had been criticised very sharply, while, at the same time, its many protagonists, the best example is Ernst Jünger, hailed technological modernity, mixing cultural criticism and technological optimism in a peculiar way. In the background of this Weltanschauung was a conception of alternative modernity compatible with the national character.

We find, comparing the German and Hungarian after-war situation, a common denominator; it was the trauma of the lost war imprinting its stamp on these years, defining the public mood of society. The term culture of defeat coined by Wolfgang Schivelbusch concisely gets the core of the situation: this means a special cultural situation having emerged after the collective shock of a lost war. It is some kind of collective neurosis, a pathological, traumatized state of national consciousness, a response to the suffered shocking experiences. The symptoms of this social illness are ranging from post-war depression, scape goating and self-chastisement to the escape of an illusory world and the stylization of defeat as moral victory. The national community having fallen into this distorted state of collective mentality is prone to create myths concerning its history and its present tasks supplied by the real surrounding world for the nation. These myths, in the opinion of Schivelbusch, at the same time, are neurotic symptoms and means of recovery for the community in a healing process:

"What neurosis is to individual, the creation of myths is to the collective. (...) Such myths (or, in the Freudian terms, fantasies) arising from frustrated desires for revenge, are the psychological mechanisms for coming to terms with defeat. Moreover, they are not merely neurotic fictions of the imaginations but also healthful protective shields or buffer zones - emotional fortresses - against a reality unbearable to the psyche" (Schivelbusch 2003, 26).

National characterologies, both in Germany and Hungary, were imbued with the attitude of cultural criticism and questioned that modern economic, social and political forms are compatible with the national essence embodying in national traits. One of the 
main targets of this criticism was egalitarian political democracy conceived as a modern corruption of right modes of political organization for the national community. Parliamentary democracy seemed to be the scape goat for the war defeat. There was a general sensitivity for elite theories - their popularity was not a mere chance in this period (Struve 1973). The representation of democracy as empty and fraudulent appearance, as a fig leaf of plutocracy governing by the means of press-manipulation, having gained its most popular description in the theory of Oswald Spengler, ${ }^{1}$ was a widely spread conviction of his period. The opposition of appearance and a hidden, secret reality was at the core of different elite theories and this idea had been associated with another antithetical notion-pair suggesting an unbridgeable gap between the false reality of masses and the truly existing reality of the elites possessing the power positions of society. The world of modernity was labelled a puppet theatre where the real actors are hiding behind the curtain and the strings of the puppets are in their hands. There is a need, suggested the theories of national characterology, for a guard change in elite positions: capitalistic money-elite must be replaced by tradition-following elites who are in close contact with the life-forces of universe and are able to lead back the nation to the historical trajectory compatible with its national traits constituting its real essence.

\section{Hungarian context}

Ressentiment, aversion to modernity, similarly to their German counterparts, was a common structural element of the theories of Hungarian national characterology. Modern world, in this conception became empty, mechanistic and soulless - it is the age of total profanation in which sacral dimension has totally disappeared from the world. This was an almost generally accepted presupposition among the authors of the

\footnotetext{
1 "The thought, and consequently the action, of the mass are kept under iron pressure - for which reason, and for which reason only, men are permitted to be readers and voters - that is, in a dual slavery - while the parties become the obedient retinues of a few, and the shadow of coming Caesarism already touches them. As the English kingship became in the nineteenth century, so parliaments will become in the twentieth, a solemn and empty pageantry. As then sceptre and crown, so now peoples' rights are paraded for the multitude, and all the more punctiliously the less they really signify (...) Money organizes the process in the interests of those who possess it, and election affairs become a preconcerted game that is staged as popular self-determination. (...) Through money, democracy becomes its own destroyer, after money has destroyed intellect. (...) And now dawns the time when the form-filled powers of the blood, which the rationalism of the Megalopolis has suppressed, reawaken in the depths. Everything in the order of dynastic tradition and old nobility that has saved itself up for the future, everything that there is of high money-disdaining ethic, everything that is intrinsically sound enough to be (...) all this becomes suddenly the focus of immense life-forces. Caesarism grows on the soil of Democracy, but its roots thread deeply into the underground of blood tradition" (Spengler 1928, 464).
} 
contemporary cultural criticism; the dichotomy of culture and civilization, coined in Germany which was a starting point of Spenglerian cultural morphology, based on this dichotomy. It was the opposition of soul imbued with sacrality and cold, totally profane intellect. The interwar world-wide crisis was conceived, first of all, as a spiritual crisis rooted in the existence of modern world totally deprived from sacral dimensions. This diagnosis involved a therapy that seemed to be inevitable to choose who accepted this premise: this was the re-sacralisation of modern world, the permeation of it with transcendence again. Regression instead of progression, re-enchantment of modern word, the resurrection of the dead God of Nietzsche and going beyond the Good Friday of modernity - these wishes frequently inspired national characterology influenced by cultural criticism.

\section{László Németh}

The conception of an alternative modernity was frequently a part and parcel of this approach. (Rohkrämer 1999) Some authors, in Hungarian interwar national characterology, outlined third-road theories in which, instead of total regression from modernity, they prophesied the coming of a new age representing a new phase of modernity compatible with national character. László Németh was a writer and ideologue; his culture criticism had been inspired on the one hand by Ortega y Gasset, the Spanish philosopher, and on the other hand the German, neoconservative Tat-circle. His conception was an amalgamation of an elite theory, a culture-centred programme of national regeneration and cultural criticism. He was convinced that European civilization has to return to the earth. Every century, he asserts, has a central idea on which the intellectual and material civilization of the age is based. The $19^{\text {th }}$ century was the age of factory and the idea of gigantomaniac industrialism based on a shallow calculative rationalism, dominated the whole life. One of the main vices of the $19^{\text {th }}$ century was that it desacralized nature; instead of revering its sacred organic wholeness this century reckoned nature as an object of exploitation. Human being had been torn out of the nature and became a one dimensional homo oeconomicus seeing nature exclusively as a depository of raw materials, an object waiting for exploitation

The $20^{\text {th }}$ century, in his historical philosophy, is the age of garden; this means a return of an earth-bound, human-sized existence replacing the gigantomania of the $19^{\text {th }}$ century. Németh was a typical third road thinker; capitalism and bolshevism for him were both outmoded relics of the $19^{\text {th }}$ century. His option is an interesting utopia mixing earth-bound human existence with a high-cultured elitist way of life; it can be realized in small communities devoted to horticulture and high culture at the same time; the homo oeconomicus will be replaced by the homo aesthetico-culturalis. In his utopistic essay entitled Kapások (Gardeners with hoes) (Németh, 1992, 805 - 842) the high cultured commune dwellers while working in the garden, are reciting poems 
of Keats by heart. Németh prophesied the revolution of quality; the $20^{\text {th }}$ century, in contrast to the $19^{\text {th }}$ century whose leading idea was quantity, is the age of quality including professional-intellectual work and handicraft. This revolution will put an end to gigantomaniac industrialism; it will be replaced by a human sized economic and social order resacralizing human life and reconciling it with nature. Hungarian national character sunken in the bottom and covered with the dregs of history must be regenerated - this historical task needs a new, national elite having recognized the requirements of new age which will be much more compatible with Hungarian national character than were the ones of industrial age.

It was another type of the theories of Hungarian national characterology which found the way out from the crisis of modernity in the crossing over into a re-sacralized era, in a regression to a pseudo-archaic (post)modern world. There were two authors whose theories, in spite of basic differences of them, belonged to this type: János Kodolányi and Béla Hamvas.

\section{János Kodolányi and Sándor Karácsony}

János Kodolányi was a member of the Hungarian populist movement emerged in the interwar period. The problem of East - West relation, a traditional Leitmotif in Hungarian national characterology at the time, played an important role in his theory. What can be the historical role of the Eastern-origin Hungarian people during the time of modernity-crisis in renewing the soulless, dried Western culture? Is Hungary forever doomed to the, always at least half-successful, imitation of Western models, or can it be a mediator between the East and the over-rationalized, tired West? These questions motivated the theory of Sándor Karácsony which was one of the most original achievements of Hungarian interwar national characterology. His theory deeply influenced Kodolányi's approach; this fact requires a short detour to his thought.

Karácsony's starting point was a linguistic one: in Indo-European languages, German one is the main base of comparison for Karácsony, the complex sentences are dominated by subordinate clause structures, while in Hungarian language they are dominated by coordinate clause structure. (Karácsony 1985) Language reflects a people's attitude to reality, so its structure determines the national character: subordinate clause structure involves a dominative attitude to reality, the Faustian dynamism of the Western civilization described by Spengler, while coordinate clause structure brings forth a non-dominative attitude to the outside environment including nature and community fellows; it is an ontological tolerance, so characteristic feature of Hungarian behaviour. Hungarian nation's historical mission is a synthesization of the Eastern form and the Western cultural contents. Hungarian culture, albeit it actually exists in a pathological manner and needs an all-out regeneration, potentially is able 
to contribute to a some extend to the renovation of the dried, over-rationalized, overmechanized, soulless, crisis stricken Western civilization from the elemental, vital forces of the cosmos (Karácsony 2002, $304-305$ ).

Kodolányi accepted the main theses of the language philosophy-based national characterology of Sándor Karácsony and shared his cultural criticism as well. Starting from the culture - civilization antithesis, he explained a deeply antimodernist theory of culture. Culture, according to him, had arisen in premodern, archaic communities living in accordance with the cosmos. The core of every culture is a collective belief in a transcendent origin symbol-system (Kodolányi 2003, 102) maintained by a special kind of human being, the homo magus; the dominant human type of modernity, the homo sapiens doomed to live in an uprooted mode of existence. This truncated kind of people, has been cut from enlivening cosmic forces, is the creator and the creature of the Western civilization at the same time. He is a deeply uncultured being, a crowd-animal, the well-known Massen-Tier of German cultural criticism, because he is doomed to exist in the distorted way of life of technical civilization which, in the lack of a transcendent depth - see to this the flach-tief antithesis of Spengler - is a mere animal vegetation, a subhuman mode of existence. The breakthrough to modernity, in the theory of Kodolányi, is the Fall, the original sin whose main consequence is the expulsion of mankind from the Paradise. The throne of God, since the beginning of modernity, has been usurped by Lucifer (Kodolányi 2003, 104): fascism, communism and liberal capitalism are equally the fruits of the tree of modernity: they have been connected by the affirmation of technical civilization.

\section{The theory of Béla Hamvas}

Hamvas belonged to the front-generation whose view of life, had deeply been influenced by war experiences acquired at the Russian and Italian fronts in 1916 - 1917. His intellectual position was very peculiar in Hungarian interwar culture. He was not a professional philosopher and he didn't want to be. He was an outsider, consciously remained outside the academic circles. He was a librarian in the Public Library of Budapest and his many-branched interest was organized by a strong cultural critical attitude culminating in the radical rejection of modernity. In the focus of his life-strategy was the desire of self-salvation for which he got hold of the wide spectrum of culture from Eastern and European philosophy and history to literature. Having been influenced by the contemporary existence philosophies and life philosophies, first of all Jaspers, Heidegger and Nietzsche, moreover Chinese and Indian philosophies and religious doctrines he developed a very special and esoteric world view focusing upon the notions of crisis, tradition and realization (Thiel 2002). The most appropriate definition concerning the core of his thought has been given by one of his interpreters, 
Endre Török who positioned him as the last and maybe the greatest representative of sacral metaphysics in European thought (Török 1988, 553).

Crisis-feeling was a widely shared emotional attitude in the post-war years, especially in the defeated countries; Hungary was deeply imbued by this attitude. The Historical Greater Hungary, after the collapse of the Austro-Hungarian Monarchy, had been diminished in a drastic way: it lost two thirds of its by-gone territory and a half of its bygone population. This situation, as it was mentioned above, proved a hot bed for the culture of defeat and was, borrowing the term of István Bibó, the most significant political thinker in the $20^{\text {th }}$ century, the starting point of communal-political hysteria by which the Hungarian national community having been dominated to our days.

This situation was the background for Hamvas's conception on the after-war crisis which, in his interpretation, is not a transitional historical event limited to the interwar era. Crisis, for him, is a spiritual phenomenon having accompanied the whole history of mankind, albeit the age of modernity has an emphatic importance in this history. During the process of world history, in the theory of Hamvas, the ancient theocentric world view has been replaced by an anthropocentric one. The most fatal consequence of this process is the breaking away of modern mankind from the lifegiving forces of the cosmos. The new development here is not the crisis itself, but the contemporary intellectual reflection given to the crisis, the crisis-consciousness representing itself in the after-war public mood. It is not too surprising, concerning the cultural criticism of the after-war decades, that Hamvas soon discovered Nietzsche, an obligatory orientation point for this tradition, and associated it with the ideas of the Stefan George Circle, René Guenon and Julius Evola. These influences had been moulded into form by the help of the contemporary German existence-philosophies; he had especially been grasped by the thought of Karl Jaspers whose philosophy he meticulously investigated in a long and thorough paper putting it into the framework of European philosophical thought.

How is it possible the realization of authentic existence? - it is a basic question for Hamvas through all his life, for which he gives different answers in the ensuing periods of his intellectual carrier. First, connecting to the conception of Nietzsche, his solution is a "beautiful neo-pagan-Greek attitude" and, consequently, the Brahmanic, spiritual way of life based on the doctrines of the holy books of ancient religions. The outlines of sacral metaphysics serving as a referential framework for Hamvas's national characterology emerge in the thirties; the conception of beautiful neo-paganGreek attitude appears in an essay-series published in 1934 and entitled as Mask and wreath whose leitmotif is the idea of age-shift (Hamvas 2011, 27-81).

We are at the border of two eras, Hamvas argues, we are witnesses and endurers of this transition, of the fall of the Promethean age and of the emergence of the 
Dionysian era. These two world-epochs are in antithetical relation with each other; the Promethean man is moved by a compulsive dynamism whose ideology is progress, while his Dionysian antagonist exists without this strive for an incessant activity; he only exists in harmony with the animating forces of the cosmos. The Promethean man is individual, the Dionysian man, similarly to Ernest Jünger's Typ, (Jünger 1960, 129) is wearing a mask; he is beyond the subject-object opposition, so characteristic to the vanishing Promethean epoch. Hamvas borrows the intellectual strategy of the contemporary German cultural criticism; unfolding his theory by the help of antithetical notion pairs: Promethean man - Dionysian man, banal existence - heroic existence, crowd - elite, human - posthuman, historicity - eternality etc. The bourgeois society based on contractual relations, in the Dionysian epoch, falls apart; the age of pseudoequality comes to an end, the bourgeois class society is replaced by a caste-system originated in a 'natural' ontological hierarchy. Spirit, that is Culture, survives in the little circles of creative, spiritual elite. The World is going through a process of resacralisation and life regains its metaphysical depth (Hamvas 2011, 61).

National characterology, in the interpretation of Hamvas, has to apply the methodology of different disciplines from Geistesgeschichte, ethnology, historiography, philosophical anthropology and existence-philosophy to psychology and cultural morphology. It has to be some kind of Hungarian fate-investigation (Hamvas 2011a, 255 - 264) - it is a conspicuous allusion to Frobenius' Schicksalkunde - opening the possibility for the outlining of a social-political structure compatible with the peculiarities of Hungarian national character. The starting point for Hamvas, in his own theory, is the tenet that Historical Greater Hungary had been a spiritual unity, a cultural referential framework of the five-component of Hungarian national character. This assertion was short of political irredentism, a determinant factor of the interwar Hungarian public life: Hamvas definitely refused any kind of nationalism which was labelled by him as a decomposition-product of modernity dissolving the righteous, ancient-origin social political structures.

Landscape, culture and character, in the national characterology of Hamvas, are intertwined; Historical Greater Hungary synthesized five cultural spheres, with other terms, it consisted of five sub-characters. The notion of character is associated by him with ancient origin idea of 'genius loci' - that is why he entitled his book about Hungarian national character Az öt géniusz (Five Geniuses) (Hamvas 1988) This complexity of Hungarian national character reflects the compound structure of European character consisting of seven sub-structures. Hungarian sub-characters are the next: genius of the South, genius of the West, genius of the North, genius of the East, genius of Transsylvania. The genius of the South dominates of the South-West parts of the country; it preserves the memory of the bygone Gold Age of mankind, it is the keeper of the 
remnants of the antique Greek civilization. The genius of the West is the keeper of Western European civilization; its dwelling is in West-Hungary, the genius of the North is not an independent spiritual entity; North is a cultural colony of the West. The habitat of the genius of the East is the Hungarian Great Plain, the western succinct of Asian steppe. It is the terrain of the ancient nomadic mentality, embodied by the Hungarian tribes having occupied this land a millennium ago and it having been surviving up time now. The genius of Transsylvania is the heir of the Byzantium civilization. Each genius has its own peculiarity: in the East it is an unrestricted strive for liberty, the genius of South has attained some kind of easiness originated from the harmonic coexistence of the cosmos and the social life, the genius of the West has realized a harmonious cultivation of outside environment and human nature, while the genius of Transsylvania is the upholder of the fabric of an ancient, sophisticated civilization. The harmonization of these sub-characters was only temporarily attained in Hungarian history by extraordinary personalities - this casts forward the shadow of the later disintegration of the country, Hamvas suggests.

\section{Conclusion}

However, the real irreconcilable tension is between the geniuses of the East and that of the West. Eastern, nomadic mentality in Hungary has always been revolting against the West: Hamvas, at this point, shares the well-known idea of the Hungarian national characterology concerning the antagonism of East and the West in Hungarian collective psyche. But the revolt of the East, Hamvas argues, is a mere emotional phenomenon lacking any inner meaning: it is sheer negation. It doesn't mean that the West wouldn't be in a crisis, Hamvas asserts using the patterns of the contemporary cultural criticism: modernity is, per definitionem, the age of consummated sinfulness, the epoch of casteless mob society which has forgotten the ancient tradition possessing the blueprint of a caste society exclusively compatible with the eternal order of the cosmos. But the West is in a better disposition because it at least tried, albeit without success, to recreate a spiritual Brahmanic caste whose ontological prerogative and obligation to lead the society committed to its care. Power in Hungary, Hamvas explains criticizing the Hungarian gentry mentality, has been usurped by the Kshatriya caste, the warriors. This is the cause of aggressive nationalism. In Hungary, Hamvas concludes, there is a double crisis: the fatal embrace of modernity crisis producing totalitarian despotisms which extirpate autonomous human personality on the one hand, and an inner special Hungarian crisis, on the other hand. The end-result, according to the deeply pessimistic conclusion of Hamvas, is an extremely atomized Hungarian society whose only social bind is mutual hate erupting in different situations of everyday life in an unexpected, unforeseeable manner. 


\section{Bibliography}

BENJAMIN, W. (1969): Theses on the Philosophy of History. In: W. Benjamin: Illuminations. Edited and with an Introduction by Hannah Arendt. Translated by Harry Zohn. New York: Shocken Books, $253-265$.

HAMVAS, B. (1988): Az öt géniusz. A bor filozófiája. Életünk könyvek: Budapest.

HAMVAS, B. (2011): Álarc és koszorú. In: Darabos, P. (ed.): Hagyomány. Válogatás Hamvas Béla folyóiratokban megjelent irásaiból. Budapest: Hamvas Béla Kultúrakutató Intézet, 27 - 81.

HAMVAS, B. (2011a): A magyar sorstudomány megalapítása. In: Darabos, P. (ed.), Hagyomány, Válogatás Hamvas Béla folyóiratokban megjelent írásaiból. Budapest: Hamvas Béla Kultúrakutató Intézet, 255 - 264.

JÜNGER, E. (1960): Der Arbeiter. Herrschaft und Gestalt. Ernst Jünger Werke, Band 6., Essays II. Stuttgart: Ernst Klett Verlag.

KARÁCSONY, S. (1985): A magyar észjárás. Budapest: Magvető

KARÁCSONY, S. (2002): Ocsúdó magyarság. Budapest: Széphalom Könyvmühely.

KODOLÁNYI J. (2003): Márai és a kultúra. In: Kodolányi, J. Zárt tárgyalás. Tanulmányok, vitairatok, emlékezések. Budapest: Szent István Társulat.

MOHLER, A. (1989): Die Konservative Revolution in Deutschland 1918 - 1932. Darmstadt: Wissenschaftliche Buchgesellschaft.

NÉMETH, L. (1992): Kapások. In: A minöség forradalma. Kisebbségben. Budapest: Püski, 805 - 842.

ROHKRÄMER, Th. (1999): Eine andere Moderne? Zivilisationskritik, Natur und Technik in Deutschland, 1880 - 1933. Paderborn: Schöningh.

SCHIVELBUSCH, W. (2003): The Culture of Defeat. On National Trauma, Morning, and Recovery. Transl. by Jefferson Chase. New York: Henry Holt and Company.

SPENGLER, O. (1928): The Decline of the West. Authorized translation with notes by Charles Francis Atkinson. London: George Allen \& Unwin. Volume II.

STRUVE, W. (1973): Elites Against Democracy. Leadership Ideals in Bourgeois Political Thought in Germany, 1890-1933. Princeton: Princeton University Press.

THIEL, K. (2002): Maszkjáték. Hamvas Béla Kierkegaard és Nietzsche tükrében. Veszprém: Veszprémi Humán Tudományokért Alapítvány.

TÖRÖK, E. (1988): Ami teljes és ami részleges. Hamvas Béláról. In: Hamvas Béla: Scientia Sacra. Budapest: Magvető Kiadó.

WOODS, R. (1996): The conservative revolution in the Weimar Republic. London: Macmillan.

Gábor Kovács

Research Centre of Humanities, Institute of Philosophy

Tóth Kálmán u. 4

1097 Budapest

Hungary

e-mail: Kovacs.Gabor@btk.mta.hu 